\title{
NCOR2 wt Allele
}

National Cancer Institute

\section{Source}

National Cancer Institute. NCOR2 wt Allele. NCI Thesaurus. Code C52230.

Human NCOR2 wild-type allele is located in the vicinity of 12q24 and is approximately 194

$\mathrm{kb}$ in length. This allele, which encodes nuclear receptor corepressor 2 protein, plays a role in both chromatin structural alteration and transcriptional regulation. 